\title{
Analysis of the Deadbeat Control Algorithm for Photovoltaic Grid Connected Inverter Output Current
}

\author{
http://dx.doi.org/10.3991/ijoe.v9iS6.2801 \\ Jia GUO ${ }^{1,2}$, Zhigang $\mathrm{LI}^{1}$, Yong $\mathrm{DU}^{2}$, and Chunyan CUI \\ ${ }^{1}$ Hebei University of Technology, Tianjin, China \\ ${ }^{2}$ Hebei University of Engineering, Hebei Handan, China
}

\begin{abstract}
Photovoltaic grid connected inverter is the core interface device in the photovoltaic power generation system to grid. The power quality of photovoltaic power generation system is affect by the waveform of output sinusoidal AC current directly. In this paper, current deadbeat control algorithm and a two-stage photovoltaic grid-connected inverter control strategy are proposed by analyzing the derivation of a photovoltaic grid-connected inverter. According to the grid connected Photovoltaic system features, a set of three-phase Photovoltaic grid connected inverter is designed, which rated power is $15 \mathrm{~kW}$. The deadbeat control algorithm is introduced, based on the analysis of photovoltaic grid connected inverter topology, grid connected voltage, current, power, and the current waveform distortion rate. The deadbeat control algorithm is effective to control the three phase inverter output current through the system simulation and analysis.
\end{abstract}

Index Terms-grid connected inverter, topology, deadbeat control, system simulation.

\section{INTRODUCTION}

With the problems of energy shortage and environmental pollution growing, the development of clean and renewable energy is more and more concerned in the world [1-5]. Photovoltaic power generation technology have continued development, which has become one of the main ways of utilizing solar energy in latest 20 years.

Grid connected inverter is the most important interface equipment for photovoltaic power systems and grid. The goal of system control is to achieve sinusoidal AC output, because of the output current waveform of the power quality directly affect the photovoltaic power generation systems. So the grid inverter output current control strategy to become one emphasis of the photovoltaic power generation system research [6].There are several methods that applied in inverter output current control, such as deadbeat control algorithm, PI control, spatial vector control method (SVPWM), stagnant loop control method etc [7]. As detailed in [8], the existing full-bridge-type and halfbridge-type converters have been analyzed by using the developed model and rules, and a new full-bridge-type converter structure and a compensation strategy for halfbridge-type inverter have been presented. As detailed in [9-15], some of the topologies are pointed out as the best candidates for either single PV module or multiple PV module applications.
In this paper, the deadbeat control algorithm is adopted to control the output current of $15 \mathrm{KW}$ photovoltaic inverter system through the analysis.

\section{CONTROL OF GRID-CONNECTED INVERTER}

$\mathrm{PV}$ grid-connected inverter block diagram is shown in Fig.1. The MPPT part is DC voltage and AC current cycle. The Boost circuit with three-phase inverter circuit can be independently controlled by two controllers, and PV array with multiple boost circuit of the high DC voltage output [16-18]. The MPPT with DC voltage and grid current cycle are independent, because of the Boost circuit output voltage of the solar is increased. Boost circuit according to the characteristic of the solar cell, adjusting the duty cycle to regulate the working voltage of the solar cell, thus ensuring the photovoltaic array operating at maximum power point [19-22]. Boost circuit output voltage of the solar cell is increased.

The Maximum Power Point Tracking control block is shown in Fig. 2. The control scheme provides an optimized simple and effective maximum power point tracking control algorithm (Maximum Power Point Tracking, MPPT) of the PV array maximum power output under different light and temperature conditions change. The cost of system indirect was reduced, when improving the conversion efficiency of the PV array. Synchronous rotating coordinate system, the application of an electric current vector PI control method, which both to achieve synchronization with the mains voltage of the inverter output current (power factor is one) and grid current closed-loop control. The current impact to the grid can be solving to photovoltaic power generation control system.

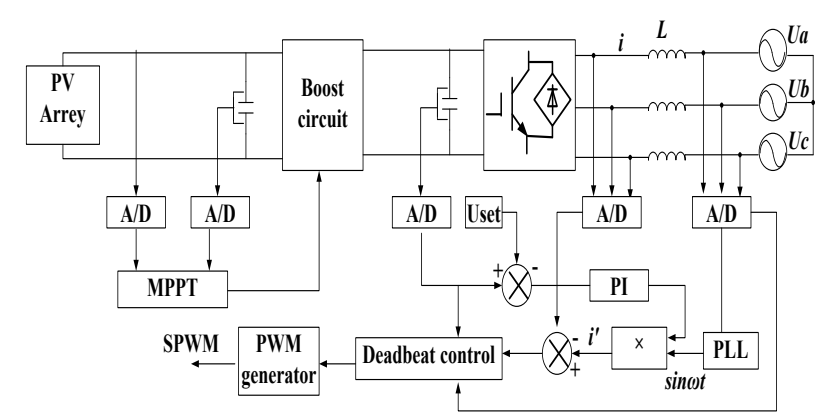

Figure 1. Structure of the inverter based on deadbeat control 


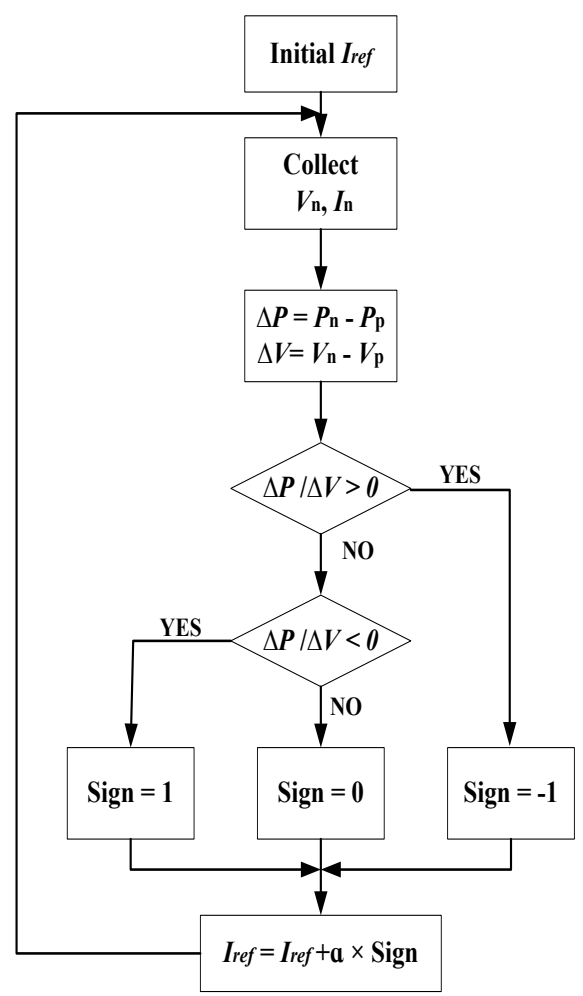

Figure 2. The control block diagram

\section{TOPOLOGY OF GRID CONNECTED INVERTER}

Grid connected inverter is core device of photovoltaic power. The function of the inverter is photovoltaic cells DC power can be converted into AC power, and transmitted to the grid.

The topology of Single-stage photovoltaic grid connected inverter is shown in Fig.3.

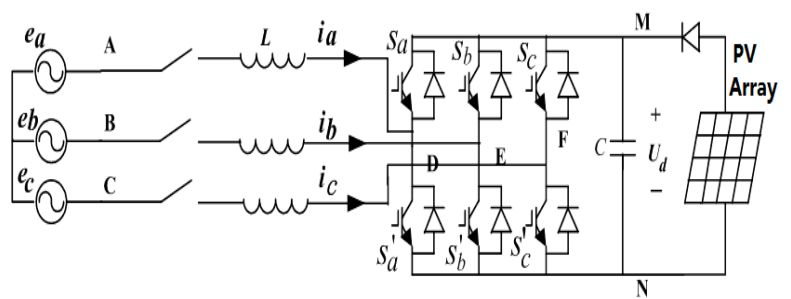

Figure 3. Topology of grid connected inverter system

Where $e_{a}, e_{b}$ and $e_{c}$ are the three phase power supply voltage, $i_{a}, i_{b}$ and $i_{c}$ are the three phase current of grid connected inverter, $L$ is the reactor inductance, $C$ is the capacity of DC side, $U_{d}$ is the voltage capacitor, $S_{a}, S_{b}, S_{c}, S_{a}^{\prime}$, $S_{b}{ }^{\prime} S_{c}{ }^{\prime}$ are the device of insulated gate transistor (IGBT).

\section{DEADBEAT CONTROL ALGORITHM}

The main objective of the proposed control is to achieve low harmonic distortion in the grid current even during grid abnormal conditions. Deadbeat control algorithm is a control algorithm depends on the circuit parameters used in the inverter system modulation algorithm will lead to inconsistent. When the cycle of control is beginning, a voltage vector, that the error tends to zero, is selection to control the inverter switching device.
The voltage equations of the loops ADNEB, BENFC, and CFNDA in Fig. 3, are shown in (1).

$$
\left\{\begin{array}{l}
L \frac{d i_{a}}{d t}+u_{D N}-u_{E N}-L \frac{d i_{b}}{d t}=u_{A}-u_{B} \\
L \frac{d i_{b}}{d t}+u_{E N}-u_{F N}-L \frac{d i_{c}}{d t}=u_{B}-u_{C} \\
L \frac{d i_{c}}{d t}+u_{F N}-u_{D N}-L \frac{d i_{a}}{d t}=u_{C}-u_{A}
\end{array}\right.
$$

Switching function is shown in (2). Taking A phase for example, when the above diode is turned on, the $d_{a}^{*}$ is 1 value and UDN equal to $U_{d}$. When the below diode is turned on, the $d_{a}^{*}$ is 0 value and UDN equal to zero. So B phase or $\mathrm{C}$ phase is the same program. Accordingly, Equation (3) can be derived.

$$
d_{K}^{*}=\left\{\begin{array}{l}
1 \\
0
\end{array}(\mathrm{k}=\mathrm{a}, \mathrm{b}, \mathrm{c})\right.
$$

Where $d_{K}^{*}$ is the description of switch status.

$$
\left\{\begin{array}{l}
u_{D N}=d_{a}^{*} U_{d} \\
u_{E N}=d_{b}^{*} U_{d} \\
u_{F N}=d_{c}^{*} U_{d}
\end{array}\right.
$$

If the (3) is substituted into (1), (4)can be derived.

$$
\left\{\begin{array}{l}
L \frac{d i_{a}}{d t}-L \frac{d i_{b}}{d t}=-\left(d_{a}^{*}-d_{b}^{*}\right) U_{d}+u_{A}-u_{B} \\
L \frac{d i_{b}}{d t}-L \frac{d i_{c}}{d t}=-\left(d_{b}^{*}-d_{c}^{*}\right) U_{d}+u_{B}-u_{C} \\
L \frac{d i_{c}}{d t}-L \frac{d i_{a}}{d t}=-\left(d_{c}^{*}-d_{a}^{*}\right) U_{d}+u_{C}-u_{A}
\end{array}\right.
$$

The capacitor voltage equation represented by the switching function of the (5).

$$
C \frac{d U_{d}}{d t}=i_{a} d_{a}^{*}+i_{b} d_{b}^{*}+i_{c} d_{c}^{*}
$$

The duty cycle of device $S_{a}, S_{b}, S_{c}$ are the $d_{a}, d_{b}, d_{c}$ which switching pulse signal during a switching cycle. As described in (6).

$$
d_{k}=\frac{t_{k}}{T_{S}} \quad(\mathrm{k}=\mathrm{a}, \mathrm{b}, \mathrm{c})
$$

During the duty cycle, $d_{a}, d_{b}$ and $d_{c}$ is equal to the switching function the average of $d_{a}^{*}, d_{b}^{*}$ and $d_{c}^{*}$ respectively. When the frequency of switching is relative high, the average sense available $d_{a}, d_{b}, d_{c}$ instead the $d_{a}^{*}, d_{b}^{*}$, $d_{c}^{*}$. 
The Equation (4) and Equation (5) are transformed to matrix form respectively. The Equation (7) indicates deadbeat current control mathematical model of the inverter.

$$
\begin{aligned}
& {\left[\begin{array}{cccc}
L & -L & 0 & 0 \\
0 & L & -L & 0 \\
0 & 0 & 0 & U_{d}
\end{array}\right] \frac{d}{d t}\left[\begin{array}{c}
i_{a} \\
i_{b} \\
i_{c} \\
U_{d}
\end{array}\right]=} \\
& {\left[\begin{array}{cccc}
0 & 0 & 0 & -\left(d_{a}-d_{b}\right) U_{d} \\
0 & 0 & 0 & -\left(d_{b}-d_{c}\right) U_{d} \\
d_{a} & d_{b} & d_{c} & 0
\end{array}\right] \times\left[\begin{array}{c}
i_{a} \\
i_{b} \\
i_{c} \\
U_{d}
\end{array}\right]} \\
& +\left[\begin{array}{cccc}
1 & -1 & 0 & 0 \\
0 & 1 & -1 & 0 \\
0 & 0 & 0 & 0
\end{array}\right] \times\left[\begin{array}{l}
u_{a} \\
u_{b} \\
u_{c} \\
0
\end{array}\right]
\end{aligned}
$$

If the (7) is discrete, taking $\triangle T$ finite increment instead approaches zero the limit of zero. when the switching frequency is relatively high, $\triangle T$ can be instead of $T_{s}$. That is $d_{t}$ equal to $\triangle T$, Ts. So the (8) can be derived.

$$
\frac{d i_{k}}{d t}=\frac{i_{k}-i_{k}}{T_{S}},(\mathrm{k}=\mathrm{a}, \mathrm{b}, \mathrm{c})
$$

Where $T_{S}$ is the time of switching period, $i_{K}$ is the actual output current of the $\mathrm{k}$ phase in the inverter, $i_{K}{ }^{\prime \prime}$ is $\mathrm{k}$ phase compensation current value.

If the (8) is substituted into (7), thus (9) can be derived.

$$
\left\{\begin{array}{l}
d_{a}=\frac{1}{3 U_{d}}\left[\frac{L}{T_{S}}\left(-2 x_{a}+x_{b}+x_{c}\right)+\left(2 u_{A}-u_{B}+u_{C}\right)\right]+\frac{1}{2} \\
d_{b}=\frac{1}{3 U_{d}}\left[\frac{L}{T_{S}}\left(x_{a}-2 x_{b}+x_{c}\right)+\left(u_{A}-2 u_{B}+u_{C}\right)\right]+\frac{1}{2} \\
d_{c}=\frac{1}{3 U_{d}}\left[\frac{L}{T_{S}}\left(x_{a}+x_{b}-2 x_{c}\right)+\left(u_{A}+2 u_{B}+2 u_{C}\right)\right]+\frac{1}{2}
\end{array}\right.
$$

Where $x_{a}=i_{a}{ }^{\prime \prime}-i_{a}, x_{b}=i_{b}{ }^{\prime \prime}-i_{b}, x_{c}=i_{c}{ }^{\prime \prime}-i_{c}$.

The $d_{a}, d_{b}$ and $d_{c}$ can be use to control the IGBT devices. The PV grid connected inverter output current $i_{k}$ is equal to the compensation current $i_{K}$ " in a switching cycle.

\section{SimUlation AND ANALYSIS}

Deadbeat control algorithm is applied in PV grid connected inverter analysis, and the power is $15 \mathrm{~kW}$. In full load state, the grid voltage, current, the waveform distortion rate of grid connected current are researched.

The Fig.4 indicated the grid voltage waveform in full load, and Fig. 5 indicated the grid current waveform in full load. The grid current distortion rate of only $1.4 \%$ distortion rate can be seen from the Fig.6, which is very small. As can be seen from Fig.7, the grid power factor is reached to 1.0 , that is issued by the current is $100 \%$ active current. But the reactive power 0 is inaccurate in Fig.7. The actual power factor of this system is 0.997 through calculation of the total active power $14.09 \mathrm{KW}$ and the apparent power $14.13 \mathrm{KW}$.

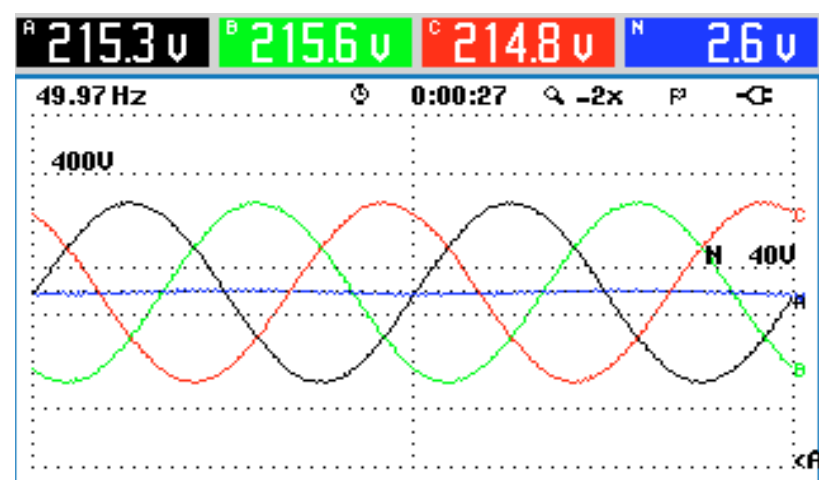

Figure 4. Grid voltage waveform in full load

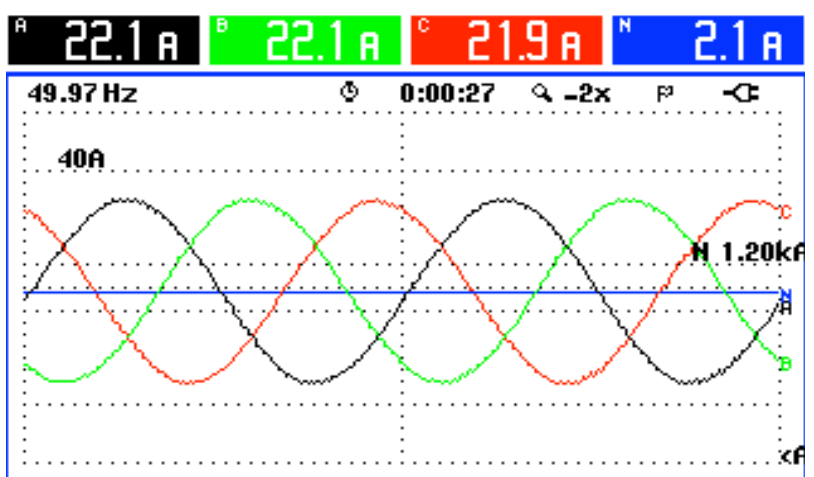

Figure 5. Grid current waveform in full load

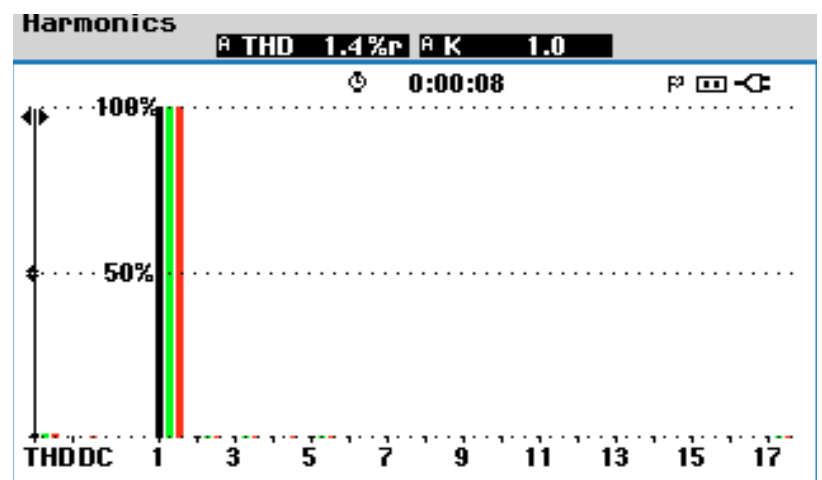

Figure 6. Distortion rate of Grid current in full load

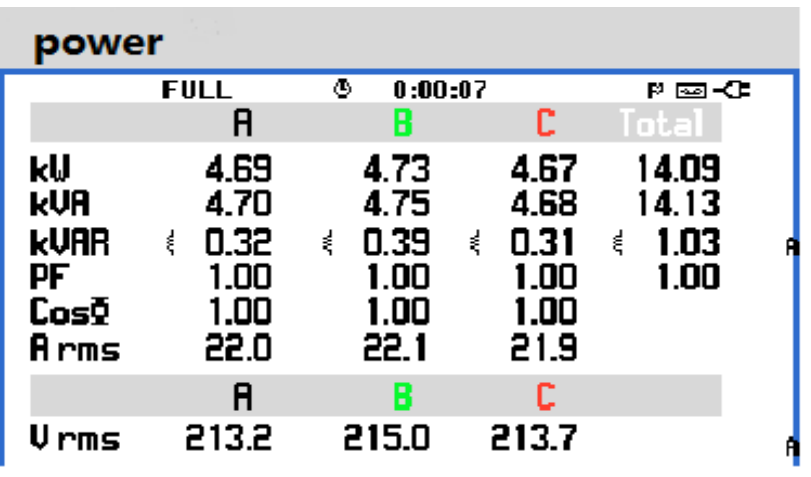

Figure 7. Grid power chart in full load 


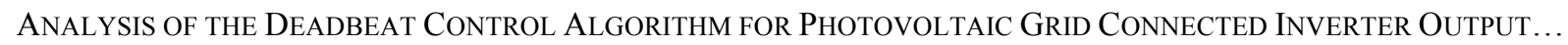

When the light intensity decreases, the power generation is in the case of $50 \%$ of the power. Fig. 8 indicated Grid voltage waveform in 50\% load. Fig.9 indicated Grid current waveform in 50\% load. Fig. 10 shows indicated Distortion rate of Grid current waveform in $50 \%$ load. The Fig. 11 indicated the chart of power generation grid power in $50 \%$ load.

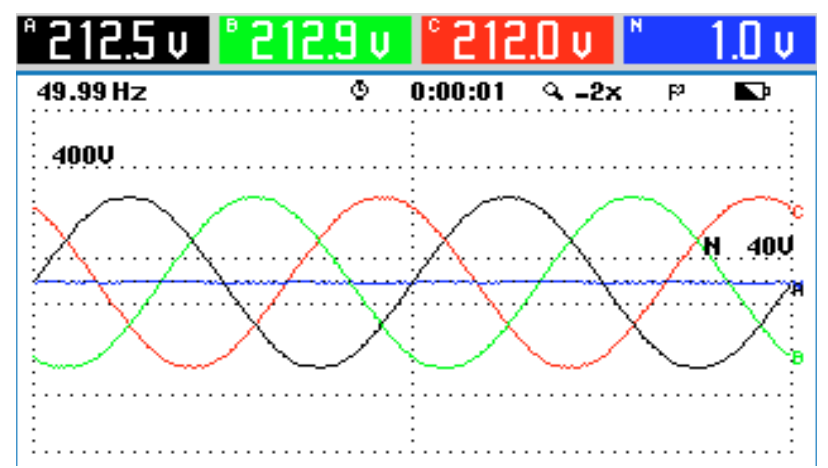

Figure 8. Grid voltage waveform in $50 \%$ load

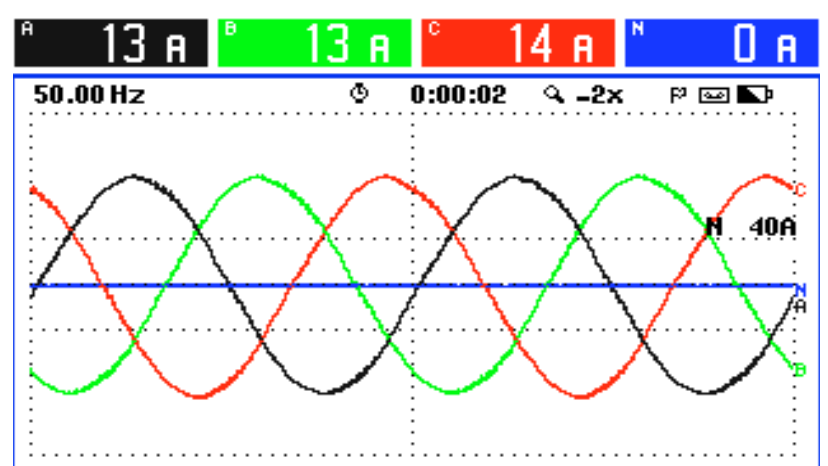

Figure 9. Grid current waveform in $50 \%$ load

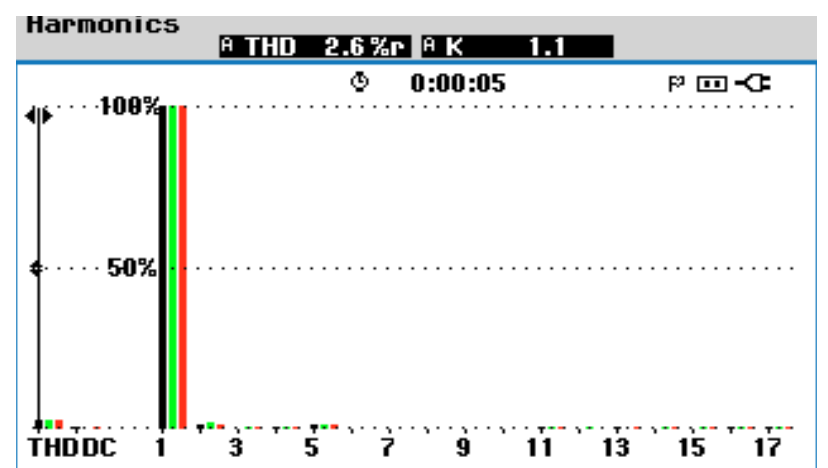

Figure 10. Distortion rate of Grid current in 50\% load

\begin{tabular}{|c|c|c|c|c|}
\hline \multicolumn{5}{|c|}{ power } \\
\hline & FULL $_{\text {A }}$ & $\begin{array}{l}\text { 0:00:05 } \\
B\end{array}$ & C & $F^{2}$ 回 \\
\hline $\begin{array}{l}\text { kU } \\
\text { kUA } \\
\text { kURR } \\
\text { PF } \\
\text { Cos } \\
\text { Prms }\end{array}$ & $\begin{array}{r}2.83 \\
2.85 \\
0.33 \\
0.99 \\
1.00 \\
13.4\end{array}$ & $\begin{array}{r}2.84 \\
2.86 \\
0.32 \\
0.99 \\
1.00 \\
13.4\end{array}$ & $\begin{array}{l}2.85 \\
2.87 \\
0.34 \\
0.99 \\
0.99 \\
13.5\end{array}$ & $\begin{array}{r}8.52 \\
8.57 \\
0.98 \\
0.99\end{array}$ \\
\hline Urms & $\begin{array}{c}\text { म } \\
212.7\end{array}$ & $\begin{array}{c}\text { B } \\
213.2\end{array}$ & $\begin{array}{c}\complement \\
212.3\end{array}$ & \\
\hline
\end{tabular}

Figure 11. Grid power chart in 50\% load
It is no difference between voltage waveform in Fig. 8 and Fig.4, because the grid for this small system is an infinite system, also the voltage of the system will not change. As can be seen from the Fig.9, the valid values of current dropped by half, but the sinusoidal waveform of grid current is still well. The distortion rate of grid current waveform is $2.4 \%$, which can be seen in Fig. 10 . The Fig. 11 indicated the grid power factor is 0.99 at this time of the system.

\section{CONCLUSIONS}

The deadbeat control algorithm as the current closedloop control algorithm has high control accuracy, fast dynamic response characteristics to meet the photovoltaic power generation control system requirements. According to the analysis of PV grid connected inverter system, which Power is $15 \mathrm{KW}$. The results indicated the deadbeat control algorithm is effective to control three phase grid output current of the inverter. However, deadbeat control algorithm has limitations, as follows.

(1) It is depend on accurate mathematical model, circuit model based on the system state equations. Also the control degree of accuracy of the effect depends on the parameters of model, so the deviation of the model parameters will lead to the unstable region caused shock.

(2) The maximum duty of output pulse width cycle is restricted, because of sampling and calculation delay. Therefore, the pulse width must be shot when is calculated. If the delay time of the control cycle quite deadbeat control algorithm, deadbeat control can not be achieved in shot output state. The impact of the delay is getting smaller and smaller, because of the high frequency digital signal processor. It has been widely used in sampling and calculation of power electronics control.

\section{ACKNOWLEDGMENT}

The authors wish to thank the helpful comments and suggestions from my teachers and colleagues in provinceministry joint key lab of electromagnetic field and electrical apparatus reliability, hebei university of technology.

\section{REFERENCES}

[1] G. Tsengenes, G. Adamidis, "A multi-function grid connected PV system with three level NPC inverter and voltage oriented control," Solar Energy, Vol. 85, pp. 2595-2610, Nov., 2011. http://dx.doi.org/10.1016/j.solener.2011.07.017

[2] J. Madouh, N. A. Ahmed, A. M. Al-Kandari, "Advanced power conditioner using sine wave modulated buck-boost converter cascaded polarity changing inverter, "Electrical Power and Energy Systems, Vol. 43, pp. 280-289, Dec., 2012. http://dx.doi.org/ 10.1016/j.ijepes.2012.05.002

[3] W. D. Xiao, W. G. Dunford, P. R. Palmer, and A. Capel, "Regulation of photovoltaic voltage," IEEE Trans. Ind. Electron., vol. 54, pp. 1365-1374, Jun. 2007. http://dx.doi.org/10.1109/TIE. 2007.893059

[4] A. Chouder, S. Silvestre, N. Sadaoui, "Modeling and simulation of a grid connected PV system based on the evaluation of main PV module parameters," Simulation Modelling Practice and Theory, Vol. 20, pp. 46-58, Jan., 2012. http://dx.doi.org/10.1016/ j.simpat.2011.08.011

[5] K. K. Tse, B. M. T. Ho, H. S. H. Chung, and S. Y. R. Hui, "A comparative study of maximum-power-point trackers for photovoltaic panels using switching-frequency modulation scheme," IEEE Trans. Ind. Electron., vol. 51, pp. 1696-1704, Apr. 2004. http://dx.doi.org/10.1109/TIE.2004.825226

[6] N. Kasa, T. Iida, and L. Chen, "Flyback inverter controlled by sensorless current MPPT for photovoltaic power system," IEEE 
Trans. Ind. Electron., vol. 52, pp. 1145-1152, Aug. 2005. http://dx.doi.org/10.1109/TIE.2005.851602

[7] J. H. R. Enslin, M. S. Wolf, D. B. Snyman, and W. Swiegers, "Integratedphotovoltaic maximum power point tracking converter," IEEE Trans. Ind.Electron., vol. 44, pp. 769-773, Dec. 1997. http://dx.doi.org/10.1109/41.649937

[8] J. H. Park, J. Y. Ahn, B. H. Cho, and G. J. Yu, "Dual-modulebased maximum power point tracking control of photovoltaic systems," IEEETrans. Ind. Electron., vol. 53, pp. 1036-1047, Aug. 2006. http://dx.doi.org/10.1109/TIE.2006.878330

[9] B. Yang, W. Li, Y. Gu, W. Cui, and X. He, "Improved transformer less inverter with common-mode leakage current elimination for photovoltaic grid-connected power system," IEEE Trans. Power Electron, Vol. 27, pp. 752-762, Feb., 2012. http://dx.doi.org/10.1109/TPEL.2011.2160359

[10] O. Lopez, F. D. Freijedo, A. G. Yepes, P. Fernandez Comesaa, J. Malvar, R. Teodorescu, and J. Doval-Gandoy, "Eliminating ground current in a transformer less photovoltaic application," IEEE Trans. Energy Convers., Vol.25, pp. 140-147, Mar., 2010. http://dx.doi.org/10.1109/TEC.2009.2037810

[11] M. C. Cavalcanti, A. M. Farias, F. A. S. Neves, and J. L. Afonso, "Eliminating leakage currents in neutral point clamped inverters for photovolta ic systems," IEEE Trans. Power Electron., Vol.59, pp. 435-443,Jan., 2012.

[12] A. Koran, K. Sano, R. Y. Kim, and J. S. Lai, "Design of a photovoltaic simulator with a novel reference signal generator and twostage LC output filter," IEEE Trans. Power Electron.,Vol.25, pp. 1331-1338,May, 2010. http://dx.doi.org/10.1109/TPEL.2009. 2037501

[13] W. D. Xiao, N. Ozog, andW. G. Dunford, "Topology study of photovoltaic interface for maximum power point tracking," IEEE Trans. Ind. Electron.,vol. 54, pp. 1696-1704, Jun. 2007. http://dx.doi.org/10.1109/TIE.2007.894732

[14] B. Yang, W. Li, Y. Zhao, and X. He, "Design and analysis of a grid connected photovoltaic power system," IEEE Trans. Power Electron., Vol.25, pp. 992-1000, April, 2010. http://dx.doi.org/10.1109/TPEL.2009.2036432

[15] W. Yu, J. S. Lai, H. Qian, C. Hutchens, J. Zhang, G. Lisi, A. Djabbari, G. Smith, and T. Hegarty, "High-efficiency inverter with H6-type configuration for photovoltaic non-isolated AC module applications," in Proceedings of the Conference on IEEE 25th Annu. Appl. Power Electron, Feb. pp. 1056-1061,2010.

[16] A. Albertini, M. G. Masi, G. Mazzanti, L. Peretto, and R. Tinarelli, "Toward a BITE for real-time life estimation of capacitors subjected to thermal stress," IEEE Transactions on Instrumentation and Measurement, Vol.60, pp. 1674-1681, May, 2011. http://dx.doi.org/10.1109/TIM.2010.2102392

[17] S. V. Araujo, P. Zacharias, and R. Mallwitz, " Highly efficient single-phase transformerless inverters for grid-connected photo- voltaic systems," IEEE Trans. Ind. Electron., Vol.57, pp. 31183128, Sept., 2010. http://dx.doi.org/10.1109/TIE.2009.2037654

[18] R. Kadri, J. P. Gaubert, and G. Champenois, " An improved maximum power point tracking for photovoltaic grid-connected inverter based-on voltage oriented control," IEEE Trans. Ind. Electron., Vol.58, pp.66-75, Jan., 2011. http://dx.doi.org/10.1109/ TIE.2010.2044733

[19] J. M. Shen, H. L. Jou, and J. C.Wu, “ Novel transformerless grid connected power converter with negative grounding for photovoltaic generation system," IEEE Trans. Power Electron.,Vol.27, pp.1818-1829, April, 2012. http://dx.doi.org/10.1109/TPEL.2011. 2170435

[20] T. Kerekes, R. Teodorescu, P. Rodriguez, G. Vazquez, and E. Aldabas, "A new high-efficiency single-phase transformerless PV inverter topology," IEEE Trans. Ind. Electron., Vol. 58, pp.184191,Jan., 2011. http://dx.doi.org/10.1109/TIE.2009.2024092

[21] H. Xiao, S. Xie, Y. Chen, and R. Huang, “ An optimized transformerless photovoltaic grid-connected inverter," IEEE Trans. Ind. Electron., Vol. 58, pp.1887-1895, May, 2011. http://dx.doi.org/10.1109/TIE.2010.2054056

[22] J. M. Kwon, K. H. Nam, and B. H. Kwon, "Photovoltaic power conditioning system with line connection," IEEE Trans. Ind. Electron, vol. 53,pp. 1048-1054, Aug. 2006. http://dx.doi.org/10.1109/ $\underline{\text { TIE.2006.878329 }}$

\section{AUTHORS}

Jia Guo (corresponding author) is with the School of Electrical Engineering, Hebei University of Technology, Tianjin 300130, China (E-mail: guojiadq@126.com).

Zhigang Li is with the School of Electrical Engineering, Hebei University of Technology, Tianjin 300130,China(E-mail: zhigangli@163.com).

Yong Du is with the School of Information and Electrical Engineering, Hebei University of Engineering, Hebei Handan 056038, China(E-mail: yongdu@yahoo.cn).

Chunyan Cui is with the School of Electrical Engineering, Hebei University of Technology, Tianjin 300130, China (E-mail: chunyancui@yahoo.cn).

This article is an extended and modified version of a paper presented at the 2012 International Conference on Artificial Intelligence and Its Application in Industry Production (AIAIP 2012), held in Wuhan, China in December 2012. It was supported in part by the National Natural Science Foundation of China (Grant No. 61072100). Manuscript received 13 May 2013. Published as submitted by the authors 26 June 2013. 